\title{
PLA2G6 Gene
}

National Cancer Institute

\section{Source}

National Cancer Institute. PLA2G6 Gene. NCI Thesaurus. Code C38597.

This gene plays a role in apoptosis and membrane remodeling. 